\title{
A new species of Falsocaenia Pic, 1922 from Amazonian Rainforest (Coleoptera: Lycidae) with an updated key to the species
}

\section{Authors: Vinicius S. Ferreira}

This is a postprint of an article that originally appeared in Zootaxa on April 26, 2016 and can be found at http://dx.doi.org/10.11646/zootaxa.4105.5.6

Ferreira, Vinicius S. A New Species of Falsocaenia Pic, 1922 from Amazonian Rainforest (Coleoptera: Lycidae) with an Updated Key to the Species." Zootaxa 4105, no. 5 (April 26, 2016): 497-499. doi:10.11646/zootaxa.4105.5.6.

Made available through Montana State University's $\underline{\text { ScholarWorks }}$ 


\title{
A new species of Falsocaenia Pic, 1922 from Amazonian Rainforest (Coleoptera: Lycidae) with an updated key to the species
}

\author{
Vinicius S. Ferreira ${ }^{1,2}$ \\ ${ }^{1}$ Museu de Zoologia da Universidade de São Paulo (MZSP), Setor de Entomologia, Laboratório de Sistemática, Evolução e \\ Bionomia de Coleoptera, Avenida Nazaré, 481, Ipiranga, CEP: 04263-000 São Paulo-SP, Brazil. \\ ${ }^{2}$ Montana Entomology Collection, Marsh Labs, Room 50, Montana State University, Bozeman, MT 59717, USA (Current \\ address). E-mail: vinicius.sfb@gmail.com
}

While searching for Calochromini (Coleoptera: Lycidae) specimens in entomological collections and identifying other Lycidae, a new species of Falsocaenia Pic, 1922 was found in the collection of Instituto Nacional de Pesquisas da Amazônia (INPA). This genus is one of the smallest in the tribe Calopterini with 13 known species, two of which were recently described by Bocákova et al. (2012) in their revision of the genus, and can be found in Central and South America.

Falsocaenia is characterized by having the pronotum transverse, trapezoidal, with a strong and bifurcate median longitudinal carina, which forms a longitudinal groove in the distal half and the elytron, strongly reticulate, with three longitudinal costae (except for costae four, which forms humeral margin) and by the male genitalia with a slender phallus with distal portion oval or circularly enlarged (Bocákova, 2003; Bocákova et al. 2012).

The phylogenetic position of Calopterini genera was discussed in Bocákova (2005), which indicate that Falsocaenia is closely related to the Acroleptina clade (i.e. Lycomorphon Pic, 1922, Lycinella Gorham, 1884, Ceratopriomorphus Pic, 1922, Acroleptus Bourgeois, 1886). However, instead of having apterous and larviform females, as presumed for other acroleptines, Falsocaenia females are fully winged (Bocákova et al., 2012). Larvae of this genus remain unknown and few is known about the biology of the species. Herein a description of a new species from Amazonian Rainforest and an updated key to the known species is given.

\section{Material and methods}

The specimens were relaxed in hot water and detergent under a stereomicroscope. Photos were taken using a Leica M205C® attached to a computer and a Leica DFC 295 camera. Photographs of genitalia were taken using a SEM Zeiss LEO 440 camera and a Zeiss Microscope Axionskop 2. The photographs were edited in Adobe Photoshop CS6. The specimens used in this study are from INPA and from Museu de Zoologia da Universidade de São Paulo, São Paulo, Brazil (MZSP).

\section{Results \\ Falsocaenia veracruzi Ferreira, new species}

(Figs. 1-4)

Diagnosis. F. veracruzi can be distinguished from other Falsocaenia species by the dark brown elytra with yellow humeral spots; the pronotum margins, and antennomeres II and at least apex of antennomeres XI also yellow.

Description. General coloration dark brown, except humeral spots, pronotum margins antennomeres II and apex of antennomeres XI, which are yellow (Fig. 1). Interocular distance twice longer than eye diameter. Head prognathous, mandibles yellowish, hooked. Labrum transverse. Maxillary palp with coloration varying from yellow to dark brown, with segment II 6 times longer than I; III and IV subequal in length, 4 times shorter than II, that is very long compared to the others, the last securiform. Antennae serrate, with antennomeres II and XI yellow (females whole yellow, male only distal half yellow). Pronotum as long as wide, posterior margins slightly divergent, with a longitudinal carina posteriorly divergent, forming a slender areola (Fig. 2). Prosternum V shaped, with an agglomeration of setae at the posterior margin. Pro spiracle tubular. Mesoventrite transverse, connected to mesoepisternum by sternopleural plates. 
Mesepimeron expanded, with a conspicuous row of setae. Metaventrite convex, rounded, with metadiscrimen complete, reaching posterior margin of mesoventrite. Legs elongate, slender, generally dark brown. Pro- and mesocoxae short, transverse, more or less oval; metacoxae transverse, slender; trochanters tubular, yellow; femora and tibiae clavate, with the basal tip of the yellow. Elytra 5 times longer than pronotum, widened in the posterior $2 / 3$. Male genitalia symmetrical; median lobe 1.5 times longer than phallobase, broadened distally (Fig. 3), with terminal circular enlargement of phallus 1.5 times wider than parameres width in distal third. Phallobase 2.5 times shorter than median lobe, longitudinal suture absent. Female genitalia slender (Fig. 4), coxites 0.5 times longer than styli. Mediobasal projection sclerotized, directed obliquely. Valvifers shortened, basally fused, forming a ventral bridge, with posterior lateral margins divergent.

Length: $6.0 \mathrm{~mm}$. Width (across humerus): $1.8 \mathrm{~mm}$.

Distribution. Brazil: Amazonas state.

Etymology. The species name was given in honor of the author's grandmother, Vera Cruz Ferreira.

Type material. Holotype 1, ơ : Brasil-Amazonas, Serra dos Porcos, 0²5'N, 69²2'O, VII-1977, Franklin, Moore (INPA). Paratypes 2,, : same data as holotype. Paratype 1, + : Brasil—Amazonas, Manaus—Campus INPA, 22/III/1988, Amorim, N. col. (MZSP).

Taxonomic remarks. F. veracruzi sp. n. (Brazilian Amazonian Forest) resembles F. grisea Kleine, 1951 (Peru) and F. ecuadorensis Bocákova, 2012 (Equator), differing from the first by the absence of the yellow transverse stripe on elytra and from the latter by having the lateral margins of the pronotum yellow.
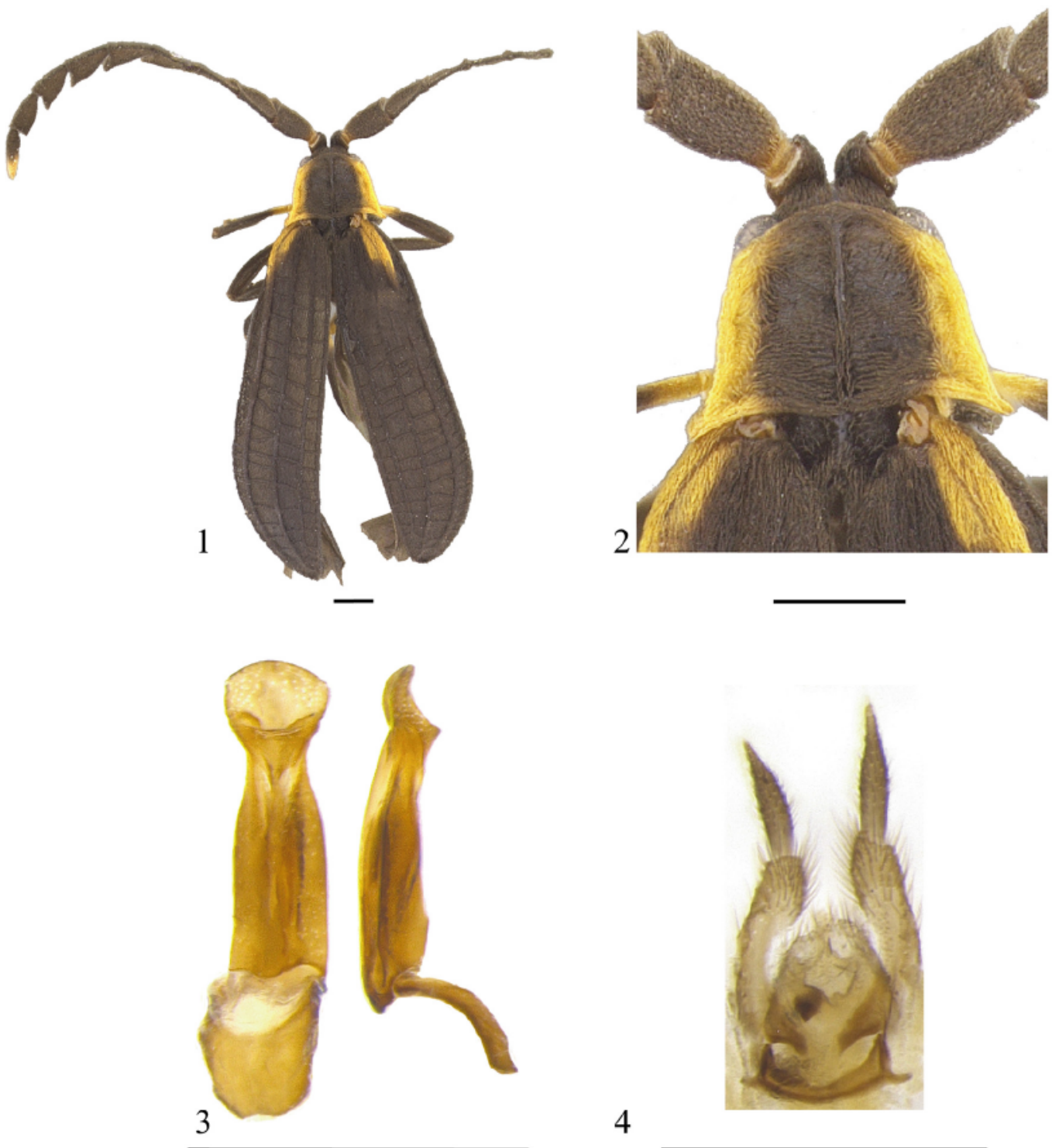

4

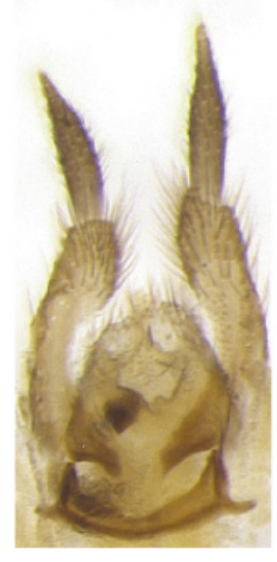

FIGURES 1-4. Falsocaenia veracruzi sp. n. 1. Dorsal view. 2. Pronotum and details of antennomeres I-III. 3. Ventral and lateral view of male genitalia. 4. Ventral view of female genitalia. Scale bar $=0,5 \mathrm{~mm}$. 
1. Elytra widened distally....

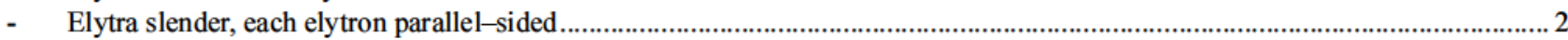

2. Transverse yellow stripe on elytra broad, present in posterior $1 / 2-4 / 5$ of elytra.

F. excavatipes Pic, 1938 (Bolivia) Transverse yellow stripe on elytra slender, present in posterior $1 / 2-7 / 12$ of elytra F. grisea Kleine, 1951 (Peru)

3. Each elytron in posterior $1 / 3$ twice wider than humeral width, parameres as long as $3 / 4$ of phallus, reaching to apical phallic constriction. F. meridana Pic, 1922 (Venezuela)

- Elytra slenderer, up to $1.7 \mathrm{x}$ wider in posterior $1 / 3$ than humeral width .

4. Longitudinal and transverse elytral costae orange, inner cells dark brown, distal portion of phallus slender, oval ..... F. aurantiacocostata Pic, 1932 (Colombia)

- Elytral coloration forming unicoloured portions, distal enlargement of phallus almost circular

5. Whole elytra orange, only basal sutural stripe slightly infuscate, distal enlargement of phallus circular

Elytra partly dark brown to black

F. decipiens (Gorham, 1884) (Panama and Costa Rica)

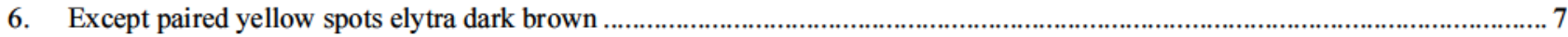

Yellow portions of elytra large, usually forming transverse or longitudinal stripes. ......................................................... 8

7. Only posterior spots in apical $1 / 6$ of elytra yellow, distal enlargement of phallus circular, wider than parameres in posterior $1 / 3 \ldots$

F. melanopteron Bocákova, 2012 (Colombia)

Most of elytra black, only humeral spots yellow

F. longehumeralis Pic, 1931 (Peru)

8. Elytral apex yellow

- Elytral apex dark brown to black

9. Parameres reaching apical $1 / 8$ of phallus, elytra largely yellow, only basal $3 / 5$ of suture, two transverse median spots, and apical $1 / 6$ of elytra dark brown F. irregularis Pic, 1931 (Bolivia)

- Parameres shorter 10

10. Basal $3 / 5$ of elytra largely yellow, only sutural region in basal quarter dark brown, male genitalia slender, distal enlargement circular. F. paranana (Pic, 1922) (Argentina)

- Basal 3/5 of elytra with longitudinal black stripes .11

11. Each elytron with a yellow transverse stripe behind elytral midlength .12

- $\quad$ Each elytron with a longitudinal black stripe

F. incognitus Kleine, 1942 (Brazil)

12. Pronotum with whole lateral margins yellow, elytra with a transverse black stripe in basal $1 / 5-1 / 2$, distal enlargement of phallus circular to transversely oval.

F. apicicornis (Pic, 1922) (Peru and Colombia)

- Yellow lateral margins of pronotum slender, each elytron with longitudinal yellow stripe along primary costa 3 .

3. Pronotum margin with lateral and apex of antennnomere XI yellow F. diversecostata Pic, 1931 (Bolivia)

- Pronotum margin and apex of antennnomere XI black F. veracruzi n. sp. (Brazil) F. ecuadorensis Bocákova, 2012 (Ecuador)

\section{Acknowledgements}

To Augusto H. Loureiro (INPA), for the loan of the Lycidae and to Carlos R. F. Brandão (MZSP), for allowing the use of his photographic equipment. To Sonia A. Casari (MZSP), for allowing the use of the specimens from MZSP for this study and to Cleide Costa (MZSP) and Henrique M. Rodrigues (Cleveland Museum of Natural History) for the English corrections and for the careful reading of the manuscript of this paper. I am also very grateful to Conselho Nacional de Desenvolvimento Cientifico e Tecnológico (CNPq) of Brazil for the scholarship (process 202559/2015-7) that allowed me to continue the study of the Lycidae. This is a contribution of the Montana Agricultural Experiment Station.

\section{References}

Bocákova, M. (2003) Revision of the tribe Calopterini (Coleoptera, Lycidae). Studies on Neotropical Fauna and Environment, 38 (3), 207-234. http://dx.doi.org/10.1076/snfe.38.3.207.28169

Bocákova, M., Barancikova, B. \& Nascimento, E.A. (2012) Revision of the genus Falsocaenia (Coleoptera: Lycidae). Zootaxa, 3478, 282-296. 